\title{
Stimulation of Streptomycin-Resistant Bacteria in the Rhizosphere of Leguminous Plants
}

\author{
BY MARGARET E. BROWN \\ Rothamsted Experimental Station, Harpenden, Hertfordshire
}

(Received 29 September 1960)

\begin{abstract}
SUMMARY
Bacteria which were resistant to streptomycin and rose bengal were preferentially stimulated in the rhizospheres of several plant species as compared with those in the soil away from the rhizosphere. Leguminous plants were the most effective and clover plants as young as 6 days had some effect. The separate and combined effects of rose bengal and streptomycin in the isolation medium were examined. Rose bengal alone had little effect on bacterial numbers, whereas streptomycin alone decreased them. The two substances together affected rhizosphere numbers strikingly but inconsistently. The bacteria from rhizosphere and soil were grouped according to their nutritional requirements. Chromogenic bacteria with simple requirements were the most abundant forms resistant to streptomycin + rose bengal in the rhizosphere and a species of Flavobacterium was especially favoured.
\end{abstract}

\section{INTRODUCTION}

Media for the isolation of soil fungi usually have antibacterial agents added, otherwise bacterial growth spreads over the fungal colonies. Several such agents have been used. Martin (1950) found that a mixture of streptomycin + rose bengal at 30 and $15 \mathrm{mg} . / \mathrm{l}$., respectively, was very effective. Rose bengal restricts fungal colony size and is also bacteriostatic; streptomycin inhibits only the bacteria. Martin found that the few bacteria which did develop in media containing these substances did not interfere with or decrease fungal counts. Bakerspigel \& Miller (1953) used streptomycin in media for the isolation of Heterosporium iridis and found that it inhibited equally bacteria from soil and from the rhizospheres of iris, potato and bean. In contrast Peterson (1957), with media containing streptomycin + rose bengal found enough bacteria on plates prepared from the rhizosphere of clover plants to interfere with fungal isolations, but not on plates prepared from the corresponding non-rhizosphere soil. There was thus a preferential stimulation of the resistant bacteria in the rhizosphere; sugar beet and wheat had a similar effect but less so than the leguminous species. Such preferential stimulation does not seem to have been recorded previously and further investigation appeared worth while.

\section{METHODS}

Rothamsted clay loam soil (Pastures field; $\mathrm{pH}$ 6.6) was used. The plants were grown in a greenhouse in $4 \mathrm{in}$. glass pots of soil, watered as required; they were not watered during $24 \mathrm{hr}$. before sampling. Rhizosphere samples were obtained by 
carefully lifting the plants and shaking them to remove most of the soil adhering to the roots, which were then cut off at the crown and dropped into a screw-capped bottle containing $100 \mathrm{ml}$. sterile distilled water; enough roots were used to provide about $1 \mathrm{~g}$. rhizosphere soil. The bottle was then shaken on a machine for $10 \mathrm{~min}$. at 150 oscillations/min. with a horizontal excursion of 1 in. Serial ten-fold dilutions were prepared and three replicate plates were made from suitable dilutions. After removing roots the contents of the bottle and the subsequent dilution were evaporated to dryness to find the dry weight of soil. The numbers of bacteria were finally calculated per g. dried soil adhering to the roots.

Non-rhizosphere samples were taken from unseeded pots of soil which had been treated similarly to the seeded ones. The surface quarter inch of soil was removed with a sterile spatula and about $1 \mathrm{~g}$. soil taken from the upper two inches and put in a bottle containing $100 \mathrm{ml}$. sterile distilled water. From this point the procedure was like that described for the rhizosphere samples.

Media for making colony counts. The numbers of bacteria in rhizosphere and nonrhizosphere soils were estimated from colony counts after incubation for 7 days at $25^{\circ}$ on glucose peptone agar (glucose, 10.0 g.; peptone, 5.0 g.; $\mathrm{KH}_{2} \mathrm{PO}_{4}$, $\mathbf{1 . 0}$ g.; $\mathrm{MgSO}_{4} .7 \mathrm{H}_{2} \mathrm{O}, 0.5 \mathrm{~g}$; agar, Difco, $20.0 \mathrm{~g}$.; tap water to 1 1.; $\mathrm{pH} \mathrm{7.0)}$ ). The numbers of bacteria resistant to streptomycin + rose bengal were estimated from colony counts made on the above medium to which streptomycin to $30 \mathrm{mg}$./ 1 . was added just before pouring the plates and rose bengal to $33 \mathrm{mg}$./l. added during the preparation of the medium (GPStRb) agar. Bacterial numbers were also estimated from colony counts after incubation for 7 days at $25^{\circ}$ on soil-extract agar $\left(\mathrm{K}_{2} \mathrm{HPO}_{4}\right.$, $0.2 \mathrm{~g}$.; agar, Difco, $20.0 \mathrm{~g}$.; soil-extract, $1000 \mathrm{ml}$., prepared by autoclaving $1 \mathrm{~kg}$. soil with 11 . distilled water for $30 \mathrm{~min}$., filtering after adding a little $\mathrm{CaSO}_{4}$, and making filtrate up to $1 \mathrm{l}$; $\mathrm{pH} 7 \cdot 0$ ).

Nutritional grouping. The bacteria from the rhizospheres and soil samples were grouped according to the method of Lochhead \& Chase (1943) by testing whether they would grow on the following media:

(a) Basal medium: glucose, 1.0 g.; $\mathrm{K}_{2} \mathrm{HPO}_{4}, 1.0$ g.; $\mathrm{KNO}_{3}, 0.5$ g.; $\mathrm{MgSO}_{4} .7 \mathrm{H}_{2} \mathrm{O}$, 0.2 g.; $\mathrm{CaCl}_{2}, 0.1 \mathrm{~g}$; $\mathrm{NaCl}, 0.1 \mathrm{~g}$.; $\mathrm{FeCl}_{3}, 0.01 \mathrm{~g}$.; distilled water to $1 \mathrm{l}$. Heat to $100^{\circ}$, filter, and adjust to $\mathrm{pH} 6 \cdot 8$.

(b) Basal medium +amino acids: basal medium $+0.05 \mathrm{~g} . / 1$. each of cysteine, alanine, proline, asparagine, glutamic acid, aspartic acid, arginine, leucine, glycine and lysine; $\mathrm{pH} 6 \cdot \mathbf{8}$.

(c) Basal medium + yeast extract: basal medium + yeast extract (Difco), 1.0 g./1.; pH 6.8.

(d) Basal medium + yeast extract + soil extract: $750 \mathrm{ml}$. basal medium $+250 \mathrm{ml}$. soil extract (prepared as above) + yeast extract $1 \cdot 0 \mathrm{~g} . / 1, ; \mathrm{pH} 6 \cdot 8$.

\section{RESULTS}

Experiments were made to test for rhizosphere stimulation of bacteria resistant to streptomycin + rose bengal with a wide range of plant species. The plants were all grown in Pastures field (Rothamsted) soil and sampled first when they were well developed and at intervals afterwards. Table 1 expresses the results in terms of the ratio number of bacteria in rhizosphere to number of bacteria in corresponding soil 
$(\mathbf{R} / \mathbf{S})$, and shows that antibiotic-resistant bacteria were preferentially stimulated in the rhizospheres of all the plants tested, but most markedly in the rhizospheres of legumes. Also, whereas legumes showed this effect as early as 6 days, plants from other families only showed it when they were quite old (53 days). Pisum sativum and Trifolium repens were selected for later experiments.

Table 1. $R / S$ ratios for resistant and non-resistant bacteria for different plant species

$\mathbf{R} / \mathrm{S}$ ratio = ratio of number of bacteria in rhizosphere to number of bacteria in corresponding soil. GP = glucose peptone agar. GPStRb = glucose peptone agar + streptomycin + rose bengal.

Age of plant (days)

12

12

12

6

21

20

20

12

29

29

53

29

53

29

53

29

53

$\quad$ Plant species
Phaseolus angularis
P. vulgaris
Vigna unguiculata
Trifolium repens
T. repens
Glycine max
Vicia faba
Pisum sativum
P. sativum
Triticum vulgare
T. vulgare
Lactuca sativa
L. sativa
Lycopersicum esculentum
L. esculentum
Raphanus sativus
R. sativus

$R / S$ ratio obtained from count on

\begin{tabular}{rr}
\hline GP agar & GPStRb agar \\
$2 \cdot 8$ & $29 \cdot 0$ \\
$19 \cdot 4$ & $27 \cdot 0$ \\
$6 \cdot 4$ & $37 \cdot 0$ \\
$6 \cdot 0$ & $20 \cdot 0$ \\
$9 \cdot 6$ & $57 \cdot 0$ \\
$21 \cdot 0$ & $866 \cdot 0$ \\
$16 \cdot 8$ & $1716 \cdot 0$ \\
$4 \cdot 0$ & $16 \cdot 0$ \\
$61 \cdot 0$ & $322 \cdot 0$ \\
$32 \cdot 0$ & $28 \cdot 0$ \\
$35 \cdot 0$ & $133 \cdot 0$ \\
$1 \cdot 8$ & $0 \cdot 02$ \\
$10 \cdot 0$ & $34 \cdot 0$ \\
$7 \cdot 7$ & $2 \cdot 2$ \\
$6 \cdot 0$ & $21 \cdot 0$ \\
$27 \cdot 0$ & $23 \cdot 0$ \\
$50 \cdot 0$ & $270 \cdot 0$
\end{tabular}

\section{Sources of variation in the examination of rhizosphere and non-rhizosphere samples of soil}

Before studying the stimulation of the streptomycin resistant flora in the rhizosphere in detail, variations due to technique and to plant variability were examined.

Replicate variance and validity of the control samples. There were too few replicates in the previous experiments to estimate the sampling variance, and the control samples were from unplanted pots and, therefore, had a different moisture régime from the planted pots. To examine these possible sources of variation, replicate pots of Pastures field soil were each seeded with one pea plant for rhizosphere samples and unseeded pots of soil were used for controls. To obtain control samples from seeded pots, cylinders of fine-mesh heavy-weight Terylene gauze were placed in each pot before sowing. The pea roots did not penetrate the gauze, but the soil in the cylinders was subjected to the same variation in moisture conditions as the soil around the pea roots. The soil samples were taken 30 days after seeding and dilution series prepared and platings made on glucose peptone agar and GPStRb agar. Table 2 shows both the numbers of bacteria and the $R / S$ ratios. The $R / S$ ratio of the resistant bacteria was everywhere higher than that of the total population. 
Table 2. Mean number of resistant bacteria and total bacterial population/g. dry weight soil in rhizosphere and in two sets of control samples

\begin{tabular}{|c|c|c|c|c|c|c|}
\hline & \multicolumn{6}{|c|}{ Counted on medium } \\
\hline & \multicolumn{3}{|c|}{ GP agar } & \multicolumn{3}{|c|}{ GPStRb agar } \\
\hline \multirow[t]{2}{*}{ Plant } & Rhizosphere & Pot soil & $\begin{array}{l}\text { Cylinder } \\
\text { soil }\end{array}$ & Rhizosphere & Pot soil & $\begin{array}{l}\text { Cylinder } \\
\text { soil }\end{array}$ \\
\hline & \multicolumn{6}{|c|}{ Bacteria $\times 10^{-6} /$ g. dry soil } \\
\hline 1 & 194 & $27 \cdot 8$ & $17 \cdot 4$ & 32 & $0 \cdot 63$ & $0 \cdot 17$ \\
\hline 2 & 103 & $15 \cdot 4$ & $20 \cdot 0$ & 28 & $0 \cdot 50$ & $0 \cdot 79$ \\
\hline $\mathbf{3}$ & 213 & $25 \cdot 0$ & $20 \cdot 0$ & 29 & $0 \cdot 38$ & $0 \cdot 28$ \\
\hline 4 & 261 & $14 \cdot 1$ & $17 \cdot 1$ & 39 & 0.55 & $0 \cdot 26$ \\
\hline 5 & 531 & $15 \cdot 2$ & $19 \cdot 1$ & 127 & $0 \cdot 35$ & $0 \cdot 66$ \\
\hline 6 & 246 & $18 \cdot 5$ & $9 \cdot 9$ & 41 & $0 \cdot 46$ & $0 \cdot 14$ \\
\hline \multirow[t]{3}{*}{ Average } & 258 & $19 \cdot 3$ & $17 \cdot 2$ & $49 \cdot 3$ & 0.48 & $0 \cdot 38$ \\
\hline & \multicolumn{6}{|c|}{$R / S$ ratios from colony counts on } \\
\hline & \multicolumn{3}{|c|}{ GP agar } & \multicolumn{3}{|c|}{ GPStRb agar } \\
\hline \multirow[t]{2}{*}{ Plant } & \multirow{2}{*}{\multicolumn{6}{|c|}{$\begin{array}{l}\text { Cylinder soil } \quad \text { Pot soil } \\
\text { Bacteria } \times 10^{-6} / g \text {. dry soil }\end{array}$}} \\
\hline & & & & & & \\
\hline 1 & \multicolumn{2}{|c|}{$6 \cdot 9$} & $11 \cdot 1$ & $50 \cdot 8$ & & $188 \cdot 2$ \\
\hline 2 & \multicolumn{2}{|c|}{$6 \cdot 7$} & $5 \cdot 1$ & $56 \cdot 0$ & & $\mathbf{3 5} \cdot 4$ \\
\hline 3 & \multicolumn{2}{|c|}{$8 \cdot 5$} & $10 \cdot 6$ & $76 \cdot 3$ & & $103 \cdot 6$ \\
\hline 4 & \multicolumn{2}{|c|}{$18 \cdot 5$} & $15 \cdot 3$ & $70 \cdot 9$ & & $150 \cdot 0$ \\
\hline 5 & \multicolumn{2}{|c|}{$34 \cdot 9$} & $27 \cdot 8$ & $362 \cdot 8$ & & $192 \cdot 4$ \\
\hline 6 & \multicolumn{2}{|c|}{$13 \cdot 3$} & $24 \cdot 8$ & $89 \cdot 1$ & & $292 \cdot 8$ \\
\hline Average & \multicolumn{2}{|c|}{$14 \cdot 8$} & $15 \cdot 7$ & $117 \cdot 6$ & & $160 \cdot 4$ \\
\hline
\end{tabular}

For statistical analysis the stimulation of resistant bacteria in the rhizosphere was expressed as the difference between the log values of the rhizosphere and control count on GPStRb agar and the log values of the rhizosphere and control count on glucose peptone agar. These differences were calculated for each of the six replicates and from these the mean difference was obtained. The mean difference with un-

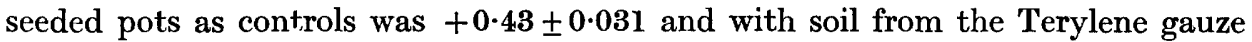
cylinder as control $+0 \cdot 49 \pm 0 \cdot 031$. These differences are individually highly significant, confirming the preferential stimulation of resistant bacteria in the rhizosphere of the pea plants. There was no significant difference in the numbers of either type of bacteria in the two sets of controls, showing that unseeded pots of soil could be used as controls, although the soil was subjected to moisture conditions different from the seeded pots.

\section{The effect of streptomycin and rose bengal separately and together in the medium}

In two experiments the effects of streptomycin and rose bengal were examined separately and together. Pea seeds were sown in Pastures field soil and unseeded pots of soil were used as controls. After 30 days, three rhizosphere and three control 
samples were taken and soil dilutions prepared. Suitable dilutions were then plated with the following agars : glucose peptone; glucose peptone + streptomycin (GPSt); glucose peptone + rose bengal (GPRb); glucose peptone + streptomycin + rose bengal (GPStRb). In another experiment two sets of plants and controls were examined similarly after 22 days. Table 3 shows the results.

\section{Table 3. The effects of streptomycin and rose bengal, separately and together,} on counts of bacteria from rhizosphere and from control soils

Peas were grown in Pastures field soil; samples taken after 30 days (Expt. 1) and 22 days (Expt. 2). $R / S$ ratio = ratio of number of bacteria in the rhizosphere to number of bacteria in corresponding soil

Sample GP agar GPRb agar GPSt agar GPStRb agar

Numbers of bacteria $\times 10^{-6} / \mathrm{g}$. dry soil as estimated from colony counts on media

Expt. 1

Rhizosphere

Control

Expt. 2

Rhizosphere Control

\begin{tabular}{|c|c|c|c|}
\hline $\begin{array}{l}478 \\
15 \cdot 3\end{array}$ & $\begin{array}{c}409 \\
14 \cdot 6\end{array}$ & $\begin{array}{r}229 \\
0 \cdot 8\end{array}$ & $\begin{array}{l}55 \\
0 \cdot 8\end{array}$ \\
\hline \multicolumn{4}{|c|}{$\mathrm{R} / \mathrm{S}$ ratio } \\
\hline 31 & 28 & 263 & 68 \\
\hline \multicolumn{4}{|c|}{ Count $\times 10^{-6} /$ g. dry soil } \\
\hline 284 & 230 & 35 & 70 \\
\hline $7 \cdot 2$ & $5 \cdot 1$ & 0.5 & $0 \cdot 2$ \\
\hline \multicolumn{4}{|c|}{$\mathbf{R} / \mathrm{S}$ ratio } \\
\hline 39 & 45 & 70 & 350 \\
\hline
\end{tabular}

$\mathbf{G P}=$ glucose peptone $; \mathbf{G P R b}=\mathbf{G P}+$ rose bengal; $\mathbf{G P S t}=\mathbf{G P}+$ streptomycin $; \mathbf{G P S t R b}=$ GP + streptomycin + rose bengal.

The presence of rose bengal alone in the medium had little effect upon the bacterial numbers, either in the soil or rhizosphere, whereas streptomycin alone prevented the development of an appreciable proportion of the population. With streptomycin + rose bengal present the numbers of bacteria/g. dry soil, as estimated from the plates made from soil samples, were affected differently in the two experiments; in Expt. 1 the numbers were the same as with streptomycin alone $\left(0.8 \times 10^{6} / \mathrm{g}\right.$. $)$, but in Expt. 2 they were decreased from $0.5 \times 10^{6}$ to $0.2 \times 10^{6} / \mathrm{g}$. Also there was a marked and irregular effect on the rhizosphere count; in Expt. 1 it was decreased from $229 \times 10^{6}$ to $55 \times 10^{6}$, but in Expt. 2 it was increased from $35 \times 10^{6}$ to $70 \times 10^{6} / \mathrm{g}$. No explanation can be offered for these divergent effects of supplementary rose bengal.

The fact that the bacteria were unaffected by rose bengal alone indicates that streptomcyin was the operative substance; this was further substantiated by the following tests in which the effects of streptomycin and rose bengal were separately examined on a range of streptomycin-resistant bacteria isolated from GPStRb agar plates. Glucose peptone agar plates were seeded with cultures of the various resistant bacteria and assay cylinders placed on the surface of the plates. Different concentrations of rose bengal (mg./l., 6600, 66, 33, 6.6) were added to one series of cylinders and different concentrations of streptomycin (mg./l., 12,000, 120, 30, 12) 
added to another series of cylinders. The plates were incubated at $25^{\circ}$ for 7 days. All the bacteria were completely inhibited by rose bengal at $6600 \mathrm{mg}$./l. and some by streptomycin at $\mathbf{1 2 , 0 0 0 ~ m g . / 1 . ; ~ l o w e r ~ c o n c e n t r a t i o n s ~ o f ~ e i t h e r ~ s u b s t a n c e ~ h a d ~ n o ~}$ effect. Thus, whatever may be the nature of the action of the streptomycin and rose bengal when together, these bacteria are resistant to both substances and it is reasonable to call the population streptomycin-resistant. The use of rose bengal in the medium may have the disadvantage of increasing the error of estimating the streptomycin-resistant population, but this is offset by its great practical value. Its function in the medium is primarily to restrict fungal growth; without it colonies are exceedingly difficult to count because of fungal overgrowth, particularly at low dilutions. For this reason rose bengal was included in all the media used later.

\section{The selective effect of the basal medium}

The glucose peptone agar used in the present work was somewhat selective and, should the streptomycin-resistant population be favoured in preference to others, the preferential stimulation of resistant types would be over-estimated. To examine the effect of the basal medium, rhizosphere and control samples from two sets of pea plants were plated with soil-extract agar, with and without the antibacterial agents; also with glucose peptone agar and GPStRb agar. Soil-extract agar was chosen for this comparison as it was the least selective of the media generally used. Table 4 shows that, as expected, the total count on the soil-extract agar without the antibacterial agents was larger than on glucose peptone agar, but the resistant population counts were similar on both media. Thus the preferential stimulation of resistant bacteria was evident with both media but appeared greater with GPStRb agar because the control resistant-count was lower. Glucose peptone agar was used as the basal medium in all further experiments because the colonies grew better and were easier to count.

Table 4. Average number of bacteria per g. dry weight of soil as estimated from soil extract and glucose peptone agars with and without antibacterial agents

\begin{tabular}{|c|c|c|c|c|c|c|}
\hline \multirow[b]{3}{*}{ Medium } & \multicolumn{6}{|c|}{ Bacteria $\times 10^{-6} /$ g. dry soil } \\
\hline & \multicolumn{3}{|c|}{ Total population } & \multicolumn{3}{|c|}{ Resistant population } \\
\hline & Rhizosphere & Control & $\mathbf{R} / \mathbf{S}$ & Rhizosphere & Control & $\mathbf{R} / \mathbf{S}$ \\
\hline Soil & 400 & $10 \cdot 0$ & 40 & 62 & $0 \cdot 6$ & 103 \\
\hline extract & 586 & $8 \cdot 0$ & 73 & 61 & $0 \cdot 7$ & 87 \\
\hline Mean & 493 & $9 \cdot 0$ & 55 & $61 \cdot 5$ & $0 \cdot 65$ & 95 \\
\hline Glucose & 238 & $8 \cdot 0$ & 30 & 57 & $0 \cdot 2$ & $\mathbf{2 8 5}$ \\
\hline peptone & 330 & $6 \cdot 3$ & 52 & 83 & $0 \cdot 2$ & 415 \\
\hline Mean & 284 & $7 \cdot 1$ & 40 & 70 & $0 \cdot 2$ & 350 \\
\hline
\end{tabular}

The properties of the bacteria

Lochhead \& Chase (1943) devised a system of grouping soil bacteria according to certain physiological criteria based on their nutritional requirements, rather than classifying them by biochemical tests, which were inadequate for any 'rational grouping helpful to an understanding of the activity or significance of these bacteria in soil'. They divided the bacteria into seven groups based on their growth in seven 
media, ranging from those organisms which could grow in a simple basal medium to those requiring unidentified substances present in both yeast and soil extracts. Lochhead \& Thexton (1947) showed that those bacteria which grew well in the simple medium were relatively more abundant in the rhizosphere, also that there was an increased incidence of bacteria requiring amino acids for maximum growth or which were stimulated by amino acids. Thus certain nutritional groups of bacteria were preferentially stimulated in the rhizosphere.

It was considered of interest in the current work to know whether the streptomycin-resistant bacteria in the rhizosphere had similar nutritional requirements and could be placed in groups known to be preferentially stimulated, or whether they had widely divergent requirements. They were compared with non-resistant bacteria in the rhizosphere and resistant and non-resistant bacteria in the corresponding soil. Lochhead \& Chase's method was used but growth in four media only was examined. These were the basal medium, basal medium + amino acids, basal medium + yeast extract and basal medium + soil extract + yeast extract. Colonies of bacteria were systematically picked, about 60 for each sample, so that all on a plate or sector were taken, and inoculated on to glucose peptone agar and checked for purity. The various nutritional media were then inoculated and after incubation for 5 days at $25^{\circ}$ the growth response of each isolate recorded by measuring the turbidity. The relative incidence of the various nutritional groups of bacteria and the estimated number of bacteria of the different groups per g. soil are shown in Table 5.

As expected there was an increased percentage in the rhizosphere of non-resistant bacteria with simple requirements and those needing amino acids. An interesting feature was that the resistant bacteria in the rhizosphere showed a greater percentage which had simple needs and a lower percentage requiring amino acids than did the non-resistant bacteria. This preferential stimulation of bacteria with simple needs was also reflected in the $R / S$ ratio: 125 with resistant bacteria as compared with 30 with non-resistant bacteria. Thus it seems that most of the preferentially stimulated resistant bacteria belonged to one nutritional group.

In addition to this property $85 \%$ of the resistant bacteria were chromogenic, producing a yellow pigment; half of these were identified as a Flavobacterium species (Bergey's Manual, 1957); the specific identity was not determined. The organism was a Gram-negative non-motile rod which produced a yellow pigment, the hue depending on the medium, being particularly bright on gelatine. Litmus milk was made alkaline; there was no proteolytic activity. Growth occurred in a wide range of carbohydrate media, sometimes with the production of acid, but never of gas; starch was not hydrolysed. The bacterium had simple nutritional requirements. The other chromogenic bacteria were also probably flavobacteria, producing bright yellow-orange pigments, which did not change colour with the medium. The specific identities were not determined. Three strains of these bacteria were found, the first having simple nutritional needs, the second required amino acids and the third required unidentified substances from yeast extract.

Of the non-resistant rhizosphere bacteria, only $33 \%$ were chromogenic and were identified as Flavobacterium spp., but with different properties from the resistant types. In the soil $19 \%$ of the resistant organisms and $12 \%$ of the non-resistant types were chromogenic. These were identified as Flavobacterium spp. 
Table 5. Nutritional groups of bacteria in rhizosphere and control soil

\begin{tabular}{|c|c|c|c|c|c|}
\hline & \multicolumn{5}{|c|}{ Resistant bacteria } \\
\hline & Rhizosphere & & Control & & $\mathbf{R} / \mathbf{S}$ \\
\hline & \multicolumn{4}{|c|}{ Plate count $\left(\times 10^{-6} / \mathrm{g}.\right)$} & \multirow[b]{2}{*}{91} \\
\hline & \multicolumn{2}{|l|}{$3 \cdot 3$} & \multicolumn{2}{|l|}{$0 \cdot 36$} & \\
\hline Nutritional groups & $\begin{array}{l}\% \\
\text { Colonies }\end{array}$ & $\begin{array}{l}\text { Estimated no. } \\
\left(\times 10^{-6} / \mathrm{g} .\right)\end{array}$ & $\begin{array}{l}\% \\
\text { Colonies }\end{array}$ & $\begin{array}{l}\text { Estimated no. } \\
\qquad\left(\times 10^{-6} / \mathrm{g} .\right)\end{array}$ & $\mathbf{R} / \mathbf{S}$ \\
\hline Grow in basal medium & 61 & $\mathbf{2 \cdot 0}$ & 44 & $0 \cdot 016$ & 125 \\
\hline Require amino acids & 20 & $0 \cdot 7$ & 56 & 0.02 & 35 \\
\hline Require yeast extract & 18 & $0 \cdot 6$ & 一 & $\mathbf{0}$ & - \\
\hline \multirow{6}{*}{$\begin{array}{l}\text { Require yeast }+ \text { soil } \\
\text { extracts }\end{array}$} & 一 & $\mathbf{0}$ & - & $\mathbf{0}$ & 一 \\
\hline & \multicolumn{5}{|c|}{ Non-resistant bacteria } \\
\hline & Rhizosphere & & Control & & $\mathrm{R} / \mathrm{S}$ \\
\hline & \multicolumn{4}{|c|}{ Plate count $\left(\times 10^{-6} / \mathrm{g}_{.}\right)$} & \\
\hline & 184 & & $7 \cdot 1$ & & 26 \\
\hline & $\begin{array}{c}\% \\
\text { Colonies }\end{array}$ & $\begin{array}{l}\text { Estimated no. } \\
\left(\times 10^{-6} / \mathrm{g} .\right)\end{array}$ & $\begin{array}{c}\% \\
\text { Colonies }\end{array}$ & $\begin{array}{l}\text { Estimated no. } \\
\left(\times 10^{-6} / \mathrm{g} .\right)\end{array}$ & $\mathbf{R} / \mathbf{S}$ \\
\hline Grow in basal medium & 50 & 93 & 43 & $\mathbf{3} \cdot \mathbf{1}$ & 30 \\
\hline Require amino acids & 25 & 46 & 12 & $0 \cdot 9$ & 51 \\
\hline Require yeast extract & 20 & 38 & 31 & $\mathbf{2 \cdot 2}$ & 17 \\
\hline $\begin{array}{l}\text { Require yeast + soil } \\
\text { extracts }\end{array}$ & 4 & 7 & 12 & $0 \cdot 9$ & 7 \\
\hline
\end{tabular}

\section{DISCUSSION}

These experiments showed that bacteria resistant to streptomycin + rose bengal were stimulated to a greater degree than non-resistant bacteria in the rhizosphere of a variety of plant species. The stimulation of resistant bacteria by legumes was greater than that produced by non-legumes, a result which was consistent with present knowledge concerning the legume rhizosphere. Also, this stimulation occurred with younger plants than with non-legumes, which might be related to the faster release of stimulatory substances; for example, Rovira (1956) showed that pea roots excreted greater amounts of amino acids during the first 21 days of growth than did oat roots. However, most of the streptomycin-resistant organisms had simple nutritional requirements, which suggested that, although amino acids might stimulate, they were not obligatory for these bacteria and the preferential stimulation of this group was not entirely dependent upon the presence of amino acids in the rhizosphere. Lochhead (1948) noted that there was a preferential stimulation of chromogenic bacteria in the rhizospheres of a variety of crop plants; in the current work, also, the streptomycin-resistant bacteria were mostly chromogenic, the predominant form being a Flavobacterium species. A possible reason for the stimulation of streptomycin-resistant bacteria in the rhizosphere might lie in their property of antibiotic resistance. Bacteria, fungi and actinomycetes are all stimulated in the rhizosphere and species of all these can produce antibiotics; it has been suggested (Brian, 1957) that the rhizosphere is a region where such production could take 
place. Thus bacteria resistant to antibiotics would have a competitive advantage over those which were sensitive, and such a group could be preferentially stimulated. Further examination of such a relationship between the various groups of soil micro-organisms in the rhizosphere is needed.

I wish to thank Dr P. S. Nutman for his interest in this work and for criticizing the manuscript and the Statistics Department, Rothamsted, for their advice.

\section{REFERENCES}

Bakerspigel, A. \& Miller, J. J. (1953). Comparison of ox gall, crystal violet, streptomycin and penicillin as bacterial growth inhibitors in plating of soil fungi. Soil Sci. 76, 123.

Bergey's Manual of Determinative Bacteriology (1957). 7th ed. Ed. R. S. Breed, E. G. D. Murray \& N. R. Smith. London: Baillière, Tindall and Cox.

Brian, P. W. (1957). The ecological significance of antibiotic production. Symp. Soc. gen. Microbiol. 7, 168.

LochHEAD, A. G. (1948). Incidence of chromogenic types in the rhizosphere noted within genus Arthrobacter. J. Bact. 55, 185.

LochHead, A. G. \& Chase, F. E. (1943). Qualitative studies of soil microorganisms: V. Nutritional requirements of the predominant bacterial flora. Soil Sci. 55, 185.

Lochhead, A. G. \& Thexton, R. H. (1947). Qualitative studies of soil micro-organisms: VII. The 'rhizosphere effect' in relation to the amino acid nutrition of bacteria. Canad. J. Res. C, 25, 20.

MARTIN, J. P. (1950). Use of acid, rose bengal and streptomycin in the soil plating method for estimating soil fungi. Soil Sci. 69, 215.

Peterson, E. A. (1957). Studies on rhizosphere fungi. Ph.D. Thesis, University of London.

Rovira, A. D. (1956). Plant root excretions in relation to the rhizosphere effect. I. The nature of root exudate from oats and peas. Plant \& Soil, 8, 178. 